\title{
Intellectuals and Political Power in Social Movements: The Parallel Paths of Fadlallah and Hizbullah ${ }^{1}$
}

\author{
Adham Saouli
}

\begin{abstract}
This paper examines the intellectual impact of Ayotallah Muhamad Hussein Fadlallah (1935-2010) on Hizbullah's political behaviour. Many depicted Fadlallah as the 'spiritual guide' and 'oracle' of Hizbullah, while others accentuated his socio-political independence and the potential he represented as an 'alternative' to Hizbullah and Iran. This study argues that Fadlallah directly influenced Hizbullah's political worldviews, but the Islamic movement's socialisation in Lebanon, its dependence on Iran, and its war with Israel have led it to pursue a separate path from Fadlallah. But despite the separation, the Ayatollah shared a common world vision with Hizbullah and the Islamic Republic, and would not have formed an alternative. The paper divides into two sections. The first examines the socio-political origins of Fadlallah and Hizbullah as an intellectual and a political movement, respectively, and conceptualises the discursive and political fields that motivate the behaviour of the two actors. The second section assesses the impact of Fadlallah's ideas on Hizbullah by focusing on three main themes: (a) Islamic liberation and resistance against injustice; (b) the Islamic state and Lebanon; and (c) Wilayat al-Fakih and Islamic Iran.
\end{abstract}

Not ideas, but material and ideal interests, directly govern men's conduct. Yet very frequently the 'world images' that have been created by 'ideas' have, like switchmen, determined the tracks along which action has been pushed by the dynamic of interest.

Max Weber ${ }^{2}$

\section{Introduction}

The intellectual work of Ayatollah Muhammad Hussein Fadlallah (1935-2010), the Lebanese Islamic-Shi'a marja'a (religious source of emulation), has shaped the political paths of Islamist revolutionaries, especially the Islamist Lebanese movement, Hizbullah. The politico-religious reformer, however, remained 'above politics'; he neither joined a

\footnotetext{
${ }^{1}$ I thank Hussein Abdulsater, Ewan Stein, and an anonymous reviewer for their useful comments and suggestions on previous versions of this article. All the paper's shortcomings remain mine alone.

2 Max Weber, 'The Social Psychology of World Religions', in H.H. Gerth and C. Wright Mills (eds), From Max Weber (London and Boston: Routledge and Kegan Paul LTD, 1974), p. 280
} 
political party, nor did he affiliate to a public religious institution. ${ }^{3}$ But misconceptions remain about Fadlallah's relationship with Hizbullah. Many in the Western and Arab worlds emphasised Fadlallah's attachment to Hizbullah, ${ }^{4}$ arguing that Fadlallah's thought and guidance had been crucial for Hizbullah's birth and political evolution. ${ }^{5}$ His endless calls for religious and political dialogue, modernist approach to religion, and politico-religious independence from Islamic Iran, on the other hand, led others to accentuate his autonomy. ${ }^{6}$ After his death, many lamented the loss of the most influential 'alternative' to Hizbullah and Iran's political and religious clout in Lebanon. ${ }^{7}$ Jamal Sankari describes Fadlallah's relation to Hizbullah as one of 'ambivalence and symbiosis'. ${ }^{8}$ Interestingly, Hizbullah's characterization of its relations to Fadlallah reflects this opacity. In its founding manifesto (1985), Hizbullah identified Imam Khomeini, not Fadlallah, as its main ideological patron; after Khomeini's death, the movement expressed loyalty to Ayatollah Khamenei, Iran's supreme leader. With Fadlallah's death, Hassan Nasrallah, Hizbullah's Secretary General, eulogised the Ayotallah as a 'merciful father, wise guide' and a teacher of dialogue and resistance against occupation and injustice. ${ }^{9}$

\footnotetext{
3 Michaelle Browers, 'Fadlallah and the Passing of Lebanon's Last Najafi Generation', Journal of Shi'a Islamic Studies, 5 (1) (Autumn 2012), pp. 29-30

4 Martin Kramer, 'The Oracle of Hizbullah: Sayyid Muhammad Husayn Fadlallah', in R. Scott Appleb (ed.) Spokesmen of the Despised: Fundamentalist Leaders of the Middle East (Chicago, IL: The University of Chicago Press, 1997).

5 Jamal Sankari, Fadlallah: the Making of a Radical Shi 'ite Leader (London: Saqi, 2005), pp. 198, 237

${ }^{6}$ Browers, Fadlallah; Hilal Khashan, 'The Religious and Political Impact of Sayyid M.H. Fadlallah on Arab Shi'ism', Journal of Shi'a Islamic Studies, 3 (4) (Winter 2010), pp. 427441. Jamal Sankari, Fadlallah: the Making of a Radical Shi'ite Leader (London: Saqi, 2005).

${ }^{7}$ David Schenker (2010) http://www.csmonitor.com/Commentary/Opinion/2010/0709/Passing-of-Shiitecleric-Fadlallah-spells-trouble-for-Lebanon. David Kenner argues that 'U.S. officials failed to appreciate the areas where their interests and Fadlallah's overlapped, both in isolating Iran and reducing the appeal of fundamentalism within Lebanon', http://www.foreignpolicy.com/articles/2010/07/06/the sheikh who got away?page= $\underline{0,0}$, accessed on 22 July 2013 . For a similar view, see also The Economist, 'He Tried to Calm Things Down', (10 July 2010), p. 48.

${ }^{8}$ Sankari, Fadlallah, p.200

${ }^{9}$ For Nasrallah's eulogy, see http://www.moqawama.org/essaydetails.php?eid=17446\&cid=128\#.UdxvlD7uWFc accessed on 13 July 2013. Naim Qassem, Hizbullah's Vice Secretary General, eulogised
} 
Fadlallah's relations to, and influence on, Hizbullah raise interesting questions on the role intellectuals play in shaping the worldviews and behaviour of political movements. How and in what capacity have Fadllallah's intellectual ideas shaped the world vision and conditioned the behaviour of Hizbullah? On the other hand, what does Hizbullah's political socialisation in the divided state of Lebanon and in its war with Israel tell us about the efficacy of these ideas?

This paper will show that Fadlallah's ideas directly have influenced Hizbullah's worldview. But it will also highlight that Hizbullah's political engagement in Lebanon and its war with Israel reveal the limits of Fadlallah's ideas. It will argue that despite Fadlallah's autonomy and his interim disagreement with Hizbullah and Iran in the 1990s, he shared a common political world vision with the two actors. As such, Fadlallah could not have formed an alternative to Hizbullah or the Iranian model as some had hoped.

The paper divides into two sections. In the first section, I examine the sociopolitical origins of Fadlallah as an intellectual, and Hizbullah as a political organisation, by distinguishing two intersecting, but separate, fields: a discursive field and a political field. This demarcation contributes to understanding the parallel social functions that Fadlallah and Hizbullah perform for the Islamic-Shi'a movement and the varying motivations that drive the behaviour of each actor. To assess the impact and limits of Fadlallah's ideas on Hizbullah, in the second section I examine three themes that are salient in his political thought: Islamic liberation and resistance against injustice; the Islamic state and Lebanon; and Wilayat al-Fakih and Islamic Iran. These themes have informed the main pillars of Hizbullah's political vision and ideals, but also represented important intellectual and political challenges for both Fadlallah and Hizbullah, which is telling about the relations that governed the two actors.

\section{Parallel Paths: Origins of an intellectual and a political movement}

As social actors, Fadlallah and Hizbullah are, among other things, the products of a Shi'iIslamic 'cultural environment'10: this environment transcends state boundaries, and

him a year later as a 'father, teacher, and educator', for the eulogy, see http://www.yahosein.com/vb/showthread.php?t=155619, accessed on 13 July 2013.

10 I take a cultural environment to mean 'the socially and culturally available array of symbols and meaning from which [social] movements can draw'. For a discussion, see Rhys 
interlocks Iran, Iraq, Lebanon, and to a lesser degrees other states of the Middle East. Intellectual and political developments in any of these countries have had direct or indirect effects on others. ${ }^{11}$ In this section, I examine the socio-political origins of both actors with the aim of demarcating the fields in which each actor operates and the functions they perform for the Shi'a social movement, specifically in Lebanon.

The socio-political origins of Fadlallah and Hizbullah can be attributed to an Islamic-Shi'a revivalism in the twentieth and twenty-first centuries. This religio-political revival was made possible with the collapse of the Ottoman Empire and the emergence of states, where Shi'a formed significant communities. ${ }^{12}$ There are three prominent processes, however, that have contributed to the rise of the Lebanese Shi'a social movement of which Fadlallah and Hizbullah became central actors. ${ }^{13}$ The first originates in Iraq where Shi'a scholars (such as Fadlallah, Mohamad Baqir al-Sadr, and Mohammad Mahdi Shamseddine) laid the foundations for Islamic political activism, initially aiming to counter then-dominant Communist ideas and movements. ${ }^{14}$ This led to the formation of the Islamic Dawa Party, which would later have a Lebanese manifestation. The second originates in the political awakening of Lebanon's Shi'a, which began with the formation of Lebanon in 1920, but later took the form of a social movement with the rise of Sayyid Musa al-Sadr (himself a student of Qum and Najaf), who struggled to integrate Lebanon's Shi'a in the Maronite-dominated Lebanese state. The final process was Khomeini's intellectual development of Wilayat al-Fakih and his opposition to the Shah, which began in the 1950s and contributed to the revolution in Iran, culminating in the

H. Williams, 'The Cultural Contexts of Collective Action: Constraints, Opportunities, and the Symbolic Life of Social Movements', in David A. Snow, Sarah A. Soule, and Haspeter Kriesi (eds), The Blackwell Companion to Social Movements (Victoria, Austrialia: Blackwell Publishing, 2004), pp. 96, emphasis original. For a discussion of a 'cultural structure' in reference to state composition in the Arab world, see Adham Saouli, The Arab State: Dilemmas of Late Formation (London and New York: Routledge, 2012),pp. 15-28.

11 See for example, H.E. Chehabi (ed) Distant Relations: Iran and Lebanon in the last 500 years (London and New York: I.B. Tauris Publishers, 2006). 12 Yitzhak Nakash, Reaching for Power: The Shi'a in the Modern Arab World (Princeton, NJ: Princeton University Press, 2006).

${ }^{13}$ A social movement involves 'sustained challenges to power-holders in the name of one or more populations living under the jurisdiction of those power-holders by means public displays dramatizing those populations' worthiness, unity, numbers, and commitment', for a detailed discussion see Charles Tilly, Regimes and Repertoires (Chicago: University of Chicago Press, 2006), pp. 179-208.

${ }^{14}$ See the article by Rachel Feder in this volume. 
establishment of the Islamic Republic. ${ }^{15}$ Whilst Fadlallah played $a$ defining role at the discursive level in Islamic-Shi'a revival, Hizbullah was one of its political manifestations.

\section{Fadlallah: A sociology of an Islamic intellectual}

Intellectuals are at the heart of contentious politics. ${ }^{16}$ As producers of knowledge and meaning, and as representatives of popular interests, ${ }^{17}$ they aspire either to transform or preserve certain values or political configurations in society. They engage in intellectual battles within discursive fields: 'such fields emerge or evolve in the course of discussion of and debate about contested issues and events'. ${ }^{18}$ Intellectuals generate what Max Weber calls 'world images', or what students of social movements define as framing: intellectuals 'assign meaning to and interpret relevant events and conditions in ways that are intended to mobilize potential adherents and constituents, to garner bystander support, and to demobilize antagonists'.19

Fadlallah was such an intellectual in the Shi'i-Islamic discursive field and social movement. Born to Lebanese parents in the Shi'i holy city of Najaf, he followed his family's tradition of pursuing religious studies. Studying in Najaf, the world's renowned centre of Shi'i religious learning, provided the young Fadlallah with a gate into the Shi'i discursive field. Although the focus in Najaf was on religious studies, this was not isolated from the sociopolitical changes that had engulfed Iraq and the broader Middle East. Early on Fadlallah showed signs of being a rebel. His passion for poetry stood against the religiously conservative Najafi scholars and his own urge to continue his studies. The ideological dominance of Communist and Arab Nationalist secular thought

\footnotetext{
15 Ervand Abrahamian, Khomeinism: Essays on the Islamic Republic (Los Angeles, CA: University of California Press, 1993).

16 Contentious politics 'involves interactions in which actors make claims bearing on someone else's interests, in which governments appear as targets, initiators of claims, or third parties. Contentious politics thus brings together three familiar features of social life: contention, collective action, and politics', see Charles Tilly, Contentious Performances (Cambridge and New York: Cambridge University Press, 2008), p. 5. 17 Michiel Baud and Rosanne Rutten, 'Introduction', in Michiel Baud and Rosanne Rutten (eds), Popular Intellectuals and Social Movements: Framing Protest in Asia, Africa, and Latin American (Cambridge: Cambridge University Press, 2005), p. 8

18 Snow, Framing Processes, 402

${ }^{19}$ Snow and Benford quoted in David A. Snow, 'Framing Processes, Ideology, and Discursive Fields', in David A. Snow, Sarah A. Soule, and Haspeter Kriesi (eds), The Blackwell Companion to Social Movements (Victoria, Austrialia: Blackwell Publishing, 2004), p. 384
} 
in Iraq propelled the young Fadlallah to reframe Islamic thought to accommodate to modern challenges; but this stood against the largely apolitical Najafi scholars, especially Ayotollah Abu Qassim al-Kho'ei, Fadlallah's mentor. Fadlallah was not alone in leading the rebellion against traditional religious and political centres, however. Among others, his colleagues Ayatollahs Mohammad Baqir al-Sadr, the founder of the Iraqi Dawa Party, and Mohammad Mahdi Shamseddine, who would later lead the Higher Islamic Shi'a Council in Lebanon, contributed works on Islamic governance, philosophy and economics in attempts to provide an Islamist alternative to Communist and secular movement in Iraq and Lebanon. ${ }^{20}$ In Iran, Khomeini advanced his treaties on 'Islamic Government', which lays the foundation for a reinterpretation of Wilayat al-Fakih. ${ }^{21}$

Fadlallah's intervention in the Shi'i-Islamic discourse reflects two main features. The first is the call for dialogue and for Wahda [unity] especially among Muslims. The second, like other Islamists who diagnosed Islamic decline and provided intellectual cures for its awakening, ${ }^{22}$ Fadlallah called for Islamic revival and liberation. Fadlallah's political thought, and indeed the broader $20^{\text {th }}$ century Shi'i-Islamic discursive field, is the product of his social milieu. His ideas originated in religious studies, but then developed as a response to sociopolitical challenges, especially in the contexts of the heterogeneous societies of Iraq and Lebanon. Here it was not enough to reiterate the (traditional) religious message: coping with the ideological competition of Communism and Arab Nationalism, which in popular discourse treated Islam as 'traditional' or at worst a 'reactionary force', required dialogue, debate, and intellectual openness. Moreover, religious diversity in Lebanon challenged the traditional belief that Islam supplied an easy religo-political cure to existing ailments. These sociopolitical constraints called for intellectual innovation.

Fadlallah believed in empowering an Islamist movement, in boosting its confidence, and transforming it from a reactive to a proactive independent social force. This requires being intellectually independent. In the introduction to his book Islam and the Logic of Power, Fadlallah argues that 'beyond the internal and external challenges', Islam should have a clear vision of all issues that are presented to it. Islamic thinkers should 'depart from a position of action, not reaction to the provocations of others' and

${ }^{20}$ See his biography at http://shamseddine.com/ar/?page id=259

${ }^{21}$ Ruhullah Khomeini, Al-Hukuma al-Islimiya (Beirut, Dar al-Quds).

22 See Ibrahim M Abu-Rabi, Intellectual Origins of Islamic Resurgence in the Modern Arab World (NY: State University of New York, 1996) 
be 'independent and comprehensive in advancing their ideas'. This is important for the 'authenticity' of their message and for their own 'confidence'. For Fadlallah, research on power is not a mere intellectual exercise; it is rather 'connected to Muslims' fateful social, political and military causes'. ${ }^{23}$ We will see in the following section how this had a direct effect on Hizbullah's world vision.

Fadlallah was not only carving an Islamic intellectual sphere, but was also locating himself as a relatively autonomous intellectual. He certainly was not the 'classbounded' organic intellectual, which Gramsci theorised about. On the other hand, he was not part of an intellectual 'class' that was immune to and isolated from socio-political concerns and activism. ${ }^{24}$ Fadlallah was, rather, a bounded intellectual, and he was bounded in two ways. Firstly, in his intellectual processes-the development of his ideas, interpretations, concepts, political frames, and perceptions-he was bounded by a pre-existing religious system: Islam, which is conveyed by the Holy Qur'an and the sayings of Prophet Mohammad (Hadith). This system defines the boundaries, and therefore the possibilities and limitations, of Fadlallah's intellectual innovation. It is a system that Fadlallah, as an Islamic scholar, could not and would not transcend; in this regard, his was an enterprise of religious re-interpretation. ${ }^{25}$ Secondly, and this is directly related to the first point, Fadlallah was bound to the popular grievances of his

\footnotetext{
${ }^{23}$ Mohammad Hussein Fadlallah, al-Islam wa Mantiq al-Quwwa [Islam and the logic of power] (Beirut: Dar al-Malak, 2003), pp.12-3. Unless otherwise indicated, all quotes from Arabic sources are of my own translation.

${ }^{24}$ In the sociology of intellectuals there are three categories: a class-bound or organic intellectual, which is tied to, and speaks on behalf of, a social class according to the Gramscian perspective; a class-less, Karl Mannehiem and Max Weber's idea that intellectuals are neither attached to social classes nor are they a class in their own; but rather intellectuals are a relatively autonomous; and finally the approach that believes that intellectual constitute a class of their own that seeks to present the interests of society as a whole. For a discussion see, Charles Kurzman and Lynn Owens, 'The Sociology of Intellectuals', Annual Review of Sociology, 28 (August 2002), pp. 63-90. ${ }^{25}$ As Weber observes, it is not 'that the specific nature of religion is simple 'function' of the social situation of the stratum which appears as its characteristic bearer'. Rather, despite the socio-political influences, any religious reinterpretation has origins in religious sources; 'such reinterpretations adjust the revelations to the needs of the religious community', see Weber, From Max Weber, pp. 269-270.
} 
social movement, which required intellectual answers that, in Fadlallah's case, meant a reinterpretation of existing religious norms and traditions. ${ }^{26}$

Here one does not fail to notice two ostensibly conflicting, but actually consistent, drives in Fadlallah's intellectual and political development. On the one hand, Fadlallah is like the Weberian, relatively autonomous, intellectual who strives to transcend political dynamics; a missionary and a universalist who encourages mutual tolerance among competing views. Fadlallah's was an Islamist mission. He strove to present Islam as an alternative to modern ideologies, but also wanted to reach, through Islam, to the universal. As such he sought to remain immune from the impurities of the political field, which involved power struggles, compromises, and pragmatism. This mission must have been influenced by his education at Najaf, which fosters the marja'a as a figure that is above politics. ${ }^{27}$ But Fadlallah could afford to maintain a level of relative autonomy from political forces and the state thanks to his socio-economic independence. In 1976 he became the Wakil [representative] for Abul Qasim Al-Kho'ei in Lebanon, which did not only mean that he could 'disseminate his juridical rulings and opinions', but could also 'collect religious taxes (zakat and khums) and donations', giving him the financial means to establish a network of religious and social services. ${ }^{28}$

The second drive is Fadlallah's attachment to socio-political activism and, hence, his direct influence on the political field. His universalist intellectual mission was not a mere philosophy, ambition, or a religious 'call'. Rather, he viewed the Islamist intellectual intervention as a form of Jihad, which in Fadlallah's understanding involves both 'intellect and practice'. ${ }^{29}$ As Abu-Rabi argues, 'Fadlallah does not look at ilm [religious knowledge] as an isolated sanctuary, and the ulama are not its isolated

26 'While seekers of pure knowledge have a "calling" to pursue the truth', argues Sadri, 'intellectuals are committed to a "mission" to the masses', Ahmad Sadri, Max Weber's Sociology of Intellectuals (New York and Oxford: Oxford University Press, 1992) pp. 108111.

${ }^{27}$ As Sankari observes: 'It was anathema to the majority of Shi'i mujtahids to establish or join modern political parties with their separate structural organization, distinct mode of activity and partisan loyalty', it was 'a serious departure from the traditional mujtahid-laymen network, and undermined the undisputed authority of the grand juriconults'. Sankari, Fadlallah, p. 71, 76. Qassem reiterates this point about Shamseddine, who always stressed that his is at 'one distance from all [political] factions', p. 21.

28 Sankari, Fadlallah, p. 161.

${ }^{29}$ Fadlallah, al-Islam, p.13. 
priests'. His political thought is directly connected to harakiya, or religo-political activism, where both political movements and proselytisers have a duty to fulfil the aims of Islamic Dawa, or mission. ${ }^{30}$ These two drives place Fadlallah at the intersection of the discursive and political fields, which can explain the opacity of his socio-political role and relationship to Hizbullah.

\section{Hizbullah and the political field}

Hizbullah, on the other hand, belonged to the political field. Its behaviour is shaped by the ideals and world images it carries from the Shi'a Islamist discursive field and, crucially for a political force, by the material balance of power. The political field is where ideals and world images transform into organised political power, namely into political ideologies, programs, and strategies. It is within the political field that cultural and religious elements are politicised by actors (parties, leaders, regimes). This transformation does not only reshape ideas, but also conditions the behaviour of a political actor. ${ }^{31}$ Hizbullah is one example.

Like Fadlallah, Hizbullah is the product of its social milieu. Its emergence and later development lies at the intersection of the aforementioned Shi'i-Islamic processes that had preceded it. ${ }^{32}$ The Islamic Revolution in Iran inspired the Islamist factions within the Shi'i social movement culminating, among other things, in the public appearance of Hizbullah in 1985. Initially, Naim Qassem, Hizbullah's vice secretary general, showed that the different Islamic formations that later became Hizbullah viewed Fadlallah as a symbol of their beliefs: 'he represented a conscious Islamic vision and programme, which supported the leader of the Islamic revolution, Imam Khomeini'. ${ }^{33}$ But whilst the Lebanese Shi'i social movement and the Shi'i discursive field shaped the ideals of Hizbullah, it was the Israeli invasion of Beirut and occupation of parts of southern Lebanon in 1982 that triggered the emergence of an organised, highly structured political actor.

It is here where Hizbullah's ideals were transferred to the political field,

\footnotetext{
${ }^{30}$ Abu-Rabi, Intellectual origins, p. 224, 239

${ }^{31}$ Adham Saouli, The Arab State: Dilemmas of Late Formation (London and New York: Routledge, 2012), pp. 15-28.

${ }^{32}$ Naim Qassem, Hizbullah: almanhag..altagruba..almustaqbal [Hizbullah: Doctrine, History, and the Future] (Beirut: Dar al-Hadi, 2008), p. 22.

${ }^{33}$ Qassem adds that these groups invited Fadlallah to play a central role in the nascent party, but he refused Ibid., p.22
} 
becoming instruments for the achievement of specific political goals. Hizbullah's 'Open Letter', its manifesto of 1985, is an illustration of this transformation: it carved the Islamist group's sphere in Lebanese and regional political fields. The manifesto defined the organisation's political identity and program, demarcating friends, allies and enemies, of which it identified the US, Israel, and their domestic allies as its the most significant. ${ }^{34}$ The Lebanese-born organisation emphasised its Islamic, globalist identity and loyalty to 'the orders, of a single, wise and just authority currently represented in the supreme Ayatollah Ruhollah al-Musawi al-Khomeini'. In so doing it differentiated itself from its Shi'a competitor, Amal. ${ }^{35}$ As we shall see in the next section, it identified the Islamic system as its main goal, on condition that the 'majority' of the Lebanese accepts it.

The world images, which were generated in the Shi'i-Islamic discursive field by Fadlallah and Khomeini, determined Hizbullah's political path, but Hizbullah's socialisation in the political field had its own dynamics. The transformation of ideals into practice involved the political mobilisation of disconcerted Lebanese Shi'a; politicoreligious indoctrination of recruits; organisation of party structures; military recruitment; and armed activities. In consequence, as we shall see below, this transformation both challenged existing power structures in Lebanon and the Middle East region, and socialised Hizbullah into them in ways that shaped the group's motivations and behaviour.

Hizbullah's location in the political field does not mean that it refrains from engaging in religious discourse or interpretation. Just as Fadlallah's intellectual production directly affected the political sphere, Hizbullah's political activity intersected with the discursive field. This, however, comes with a twist. Through its intelligentsia and religious networks, Hizbullah instrumentally employs and disseminates ideas for political purposes. ${ }^{36}$ Commenting on the call for Islamic unity, Qassim reveals the pragmatic nature of this political actor:

\footnotetext{
${ }^{34}$ For example, the manifesto considered the Lebanese Phalange as 'criminals'. For further analysis of Hizbullah's manifestos, see Joseph Alagha, Hizbullah's Documents: From the 1985 Manifesto to the 2009 Manifesto. (Amsterdam: Amsterdam University Press, 2010) ${ }^{35}$ August Richard Norton, Amal and the Shi'a: Struggle for the soul of Lebanon (Austin: University of Texas, 1987).

${ }^{36}$ As Sadri argues, the 'intelligentsia will be found more willing than intellectuals to view ideas instrumentally'. The intelligentsia 'consume' and 'disseminate' ideas, but they do
} 
Instead of getting drawn into dreams and wishes... we should seek to buttress our common characteristics at a practical level that would lead to unity in its different cultural or political or jihadist facets... [we need] not be drawn into a discussion about the sex of angels when our land is occupied and when the arrogant imperialist powers threaten our future. ${ }^{37}$

By establishing several new hawzas (religious seminaries), Hizbullah revolutionised the role of religious schools (which in Qassem's view did not offer the conditions of a political revival as they did in $\operatorname{Iran}^{38}$ ). The aim, as Abisaab observes, was 'to nurture the 'intellectual' as someone organically tied to the depressed Shi'i classes, and to spread the ideas of the party as effectively as possible'. These hawzas indoctrinate students with Khomeini's ideology, students who then go on to play an important role in disseminating Hizbullah's ideology as religious teachers, mosque leaders, proselytisers and politicians. ${ }^{39}$ Hizbullah's religio-political need to advance its own, Khomeinist, world vision reflects the presence of other competing sites in the political and discursive fields of the Shi'i social movement. ${ }^{40}$ This is also true of Ashura, (the annual commemoration of the Martyrdom of Hussein, the grandson of the Prophet) which Hizbullah's frames in ways that are conducive to its political strategy. 41

so for specific goals; they act as mediators between intellectuals and other social forces, Sadri, Max Weber's, pp. 69-70. Hizbullah's intelligentsia includes, but is not limited to, religious leaders of Hizbullah-controlled Hawzas, presidents of religious and political studies centres (such as Sheikh Shafeek Jradi and Hassan Hoballah, respectively), Hizbullah officials (Sheikh Naim Qassem, Nawaf Moussawi, Hassan Fadlallah, and Ali Fayad), and Hizbullah sympathisers (Qassem Qassir, Ahmad Majid, Tallal Atrissi).

37 Qassem, Hizbullah, pp.42-3.

${ }^{38}$ Qassem, Hizbullah, p.24.

${ }^{39}$ Rula Jurdi Abisaab, 'The Cleric as Organic Intellectual: Revolutionary Shi'ism in the Lebanese Hawzas', in H.E. Chehabi (ed) Distant Relations: Iran and Lebanon in the last 500 years (London and New York: I.B. Tauris Publishers, 2006), p. 241. Abisaab adds that Hizbullah 'brought more structure, discipline, and hierarchy to the hawzas with the aim of controlling who rise to the top on the basis of social demand and the overall benefit to Shi'a society', p. 250.

${ }^{40}$ For example, Shamseddine believed that the religious seminaries should be politically neutral and refused the curricula of the Hizbullah controlled hawzas, see Ibid., p.252. ${ }^{41}$ As Atrissi observes, Hizbullah's commemoration of Ashura 'reached high level of organisation to the extent that the movement has established schools to prepare Ashura reciters'; moreover, it holds conferences to discuss Ashura's potential for social, religious, and political mobilisation. See Talal Atrissi, Ashura: Ihyaa al-Taghier (Ashura: reviving change), in Shi'a fi Lubnan: min al tahmish ilal musharaka alfaila [The Shi'as of Lebanon: from marginalization to active participation] (Beirut: Dar Al Maarif, 2012), p. 344 . 


\section{Ideas and political power: Fadlallah and Hizbullah in the Shi'i social movement}

Having demarcated the two separate fields that motivate Fadlallah and Hizbullah, respectively, this section examines how and to what extent Fadlallah's thought influenced the world vision of Hizbullah. I explore three areas of Fadlallah's thought that mould Hizbullah's worldview: Islamic liberation and resistance against injustice; the Islamic state and Lebanon; and Wilayat al-Faqih and Islamic Iran.

I demonstrate that Fadlallah's realist approach directly informs the pragmatism underlying Hizbullah's core ideology and behaviour, which was clear from as early as the 1980s. ${ }^{42}$ On the other hand, Hizbullah's socialisation in the anarchic Lebanon of the 1980s and its prioritisation of the war with Israel reveal the limits of Fadlallah's ideas and the difficulty of reconciling his universal goals in practice. Moreover, Hizbullah's ideological, financial, and military dependence on Islamic Iran have led to the political movement's qualified departure from the Lebanese marja'a.

\section{Islamic liberation: power and the struggle against injustice}

For Fadlallah, the basis for an Islamic political awakening and liberation originates from an understanding of Islam as a revolution against oppression and injustice: 'In our view', he argues, 'the true Islamic stand is rebellion [against] and movement to change the reality of oppression and injustice.. ${ }^{43}$ Weakness is no justification for accepting injustices, unless it is part of comprehensive 'policy of gradual change'. The point of departure towards liberation for Fadlallah is to defeat the feelings of weakness and incapacity at the individual level. In the face of socio-political constraints, Fadlallah focuses on the individual as a driver of change. 'Human beings', he argued, are the 'motors of change'; it all starts with an idea, a feeling or passion in an individual and

\footnotetext{
42 According to this reading, Hizbullah did not need to pass through "an application" phase before it realised the limits of its ideology and consequently "moderate" its behaviour. The idea that Hizbullah has 'Lebanonised' and became more 'pragmatic' after the Taif Accord, which ended the Lebanese war (1975-1990), underestimates the multilayered identity of Hizbullah and it realist vision. For Hizbullah's political development and adaptation, see Judith Harik, Hezbollah: the changing face of terrorism, (London: IB Tauris, 2005); Nizar Hamzeh, In the Path of Hizbullah (New York: Syracuse University Press, 2004. Regarding Hizbullah's identity construction, see Joseph Alagha, Hizbullah's Identity Construction (Amsterdam: Amsterdam University Press, 2011).
}

${ }^{43}$ Fadlallah, al-Islam wa mantiq al-quwa, p.61 
then transforms into a practical application. ${ }^{44}$ For Fadlallah, Muslims need to draw God back into their lives and to accept that God's guidance and support of their actions will lead to 'God's promise' of eventual 'victory' against injustice. ${ }^{45}$ For him, this idea is also a means to enhance the confidence of the fighter: 'it is the practical tool in the Quran to amass the weak with power... by asking them to be self-reliant and dependent first and foremost on God'. ${ }^{46}$ Hizbullah, as we shall see below, shares this perception: it frame its survival against Israel in the 2006 war as a 'Divine Victory' and as 'God's promise'.

Whilst cognizant of the spiritual dimensions (being dependent on God) of the resistance against injustice and oppression, Fadlallah is also aware of the material basis (being self-reliant) of the struggle. Here his realism and understanding of power invites the Islamist to be attentive to socio-political conditions, to be self-reliant, and to exercise restraint in the face of external pressure. He argues that Islam's quest for power has two main reasons: first, in order for the umma to achieve its goals, by being self-reliant and by controlling its own resources; and second, to deter war. This occurs when the umma is able to amass power that 'would deter and frighten the enemy'. In this regard, Fadlallah's realism keeps the door open for the possibility of the use of violence in 'selfdefence' or as a way to 'pre-empt' the enemy. 'We are not an Islamic movement that considers violence as our only tool', Fadlallah argues. But, realist as he was, Fadlallah believed the use of violence was sometimes necessary as a way to 'deter' those (regimes and colonial powers) who threaten people's lives. ${ }^{47}$ Both aims require a careful understanding of Muslims' sources of material and spiritual power, and the investment in and concentration of potential sources of individual and social power.

Fadllalah calls upon Muslims to be realistic in their approach and to not state or seek to achieve 'fictional goals' ${ }^{48}$ Self-reliance is crucial for an independent political actor; otherwise, reliance on powerful actors, such as the colonial powers or authoritarian regimes, transforms the Islamist into a tool in the power struggles of others. The Islamist needs, through a piecemeal approach, to accumulate power and

\footnotetext{
44 Ibid., p. 264. Fadlallah is famous for continuously reiterating the following Quranic verse, which relates to this idea: 'Lo! Allah changeth not the condition of a folk until they (first) change that which is in their hearts', The Glorious Quran, p. 321.

45 Fadlallah builds on verses, 5-6 in Surat Al-Kisas, 5-6 and 39-40 in Surat al-Haj in the Quran.

${ }^{46}$ Fadlallah, al-Islam wa mantiq al-Quwa, p.68.

${ }^{47}$ Fadlallah, Min ajl al-Islam, pp. 392-3

${ }^{48}$ Fadlallah, al-Islam wa mantiq al-Quwa, p.332
} 
invest in existing economic, social and political potential to achieve independence. ${ }^{49}$ Fadlallah believes that 'power is not about excitement and reaction'; rather, it is about the constant effort to achieve goals, through planning and practical training, and through the exercise of self-restraint against external pressure. A strong leader is one who is able to control their anger, and not lose control and initiative in battle. ${ }^{50}$

Where should this power be directed? For Fadlallah, Islamic revival involves freedom from oppressive regimes and colonialism. This is a religious duty. Islam calls upon the Muslim to 'promote virtue and prevent vice', including the struggle against unjust and oppressive regimes that deviate from the mission of Islam. Political oppression against the weak and downtrodden, which takes place in the name of preserving stability and consolidating regime power, should be resisted.

The Islamic perception of the duties of the believer transcends his commitment to [the main pillars] of Sharia; rather, it also includes a commitment to participate in establishing justice and the resistance of oppression in the Umma, even if this involved the exercise of power in the process of change. ${ }^{51}$

As we shall see in the next section, the approach-violent or political-applied to achieve this change depends on the objective socio-political conditions.

Fadlallah's second religio-political goal involves freedom from colonialism and occupation. For Fadlallah colonialism has weakened the individual capacities and potential of the Islamic umma, keeping it dependent on colonial and (post-colonial) 'arrogant' powers. Intellectually, he highlights the role of 'Orientalist' studies that portray, and raise suspicions about, the Arab and Muslim worlds as weak and incapable of development. Such studies seek to strip the Muslim world from its authenticity, identity, and, therefore, power to rise. ${ }^{52}$ Like Khomeini, Fadlallah believed that the US and its proxies in the Arab and Muslim world have collaborated to prevent the Muslims from achieving true independence. Their view was that the US and the West have implanted Israel in the heart of the Middle East to extend their influence, to divide the Muslim world, and, as a consequence, have stripped the Palestinians of their land and identity. ${ }^{53}$

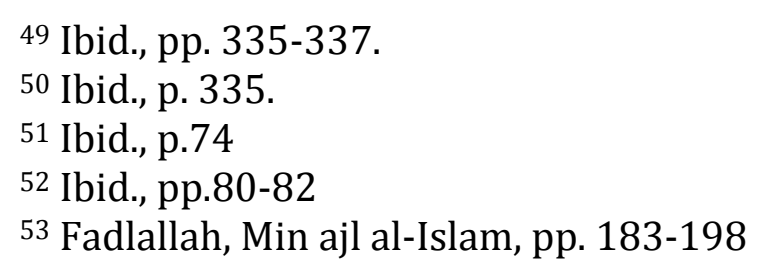


For Fadlallah, liberating Palestine and other Arab occupied territories can only be achieved through resistance, both intellectual and military. Liberation, especially of Jerusalem, is a religious duty. It is in this context that he called for resistance against the Israeli invasion and occupation of Lebanon and for wahda among political movements,regardless of their national identity, in their efforts against Israel. ${ }^{54}$ As such, given Fadlallah's intellectual and political orientation, he was placed in the camp that is in opposition to the US, its Arab allies, and Israel. For these reasons, Fadlallah represented the religious guide, whose ideas were congruent with the nascent revolutionary movement of the 1980s: Hizbullah. Unlike Shamessedine, who was close to the Amal Movement, Fadlallah represented the globalist Islamist who was clear about political change within Lebanon, and resistance against Israel. ${ }^{55}$ But in the $1980 \mathrm{~s}$ Fadlallah did not yet qualify as a marjaa; crucially also, whilst Fadlallah provided the intellectual and religious basis for Hizbullah's thinking and behaviour, thanks also to his presence in Lebanon, unlike Khomeini he neither possessed the resources required for military resistance nor the political and regional influence a major state like Iran could supply. Islamic Iran, with its declared stand against Israel and Arab regimes in alliance with the US, provided a regional opportunity for Hizbullah to rise and fight Israel. Khomeini, a successful revolutionary, head of a state, and an influential Islamist scholar, represented the logical patron for the nascent revolutionary Islamic movement.

But Fadlallah's political thought has nonetheless directly influenced the world images of Hizbullah. In its Open Letter of 1985, which was addressed to the 'Downtrodden', Hizbullah identified its main enemies as 'the US, France, and Israel' and their domestic ally, the Lebanese Phalange. Despite its revolutionary and confrontational rhetoric, however, Hizbuallah's realism is evident in its discourse and behaviour as early as $1985 .{ }^{56}$ As we shall see below, it called for the establishment of an Islamic state, but this was conditioned on its acceptance by a majority in Lebanon. Its

\footnotetext{
54 Ibid., pp. 51-90; see also Rola el-Husseini, 'Resistance, Jihad, and Martyrdom in Contemporary Lebanese Shi'a Discourse', Middle East Journal 62 (3) (Summer 2008), pp. 399-414.

${ }^{55}$ After the Israeli invasion of 1982, Shamssedine called for 'civil resistance', an idea that would then fade away.

${ }^{56}$ See the Open Letter in see Hassan Fadlallah, Al-Khiyar al akhar: Hizbullah, assira alzatiya wal mawkef [The Alternative Choice: Hizbullah, a stand and a biography of the organisation) (Beirut, Dar al-Hadi: 1994), pp. 184-213.
} 
pragmatist nature is in fact reflected in the priority it has accorded to military resistance against Israel over any other ideological goals. ${ }^{57}$

Unlike other Islamic movements that have engaged in 'offensive Jihad', Hizbullah's is a 'defensive Jihad'. As opposed to the 'offensive Jihad', which involves Muslims confronting others and invading their territories, and which in Hizbullah's ideology can only be called for by the Prophet or the infallible Imam, defensive Jihad involves resistance against occupation, and defence and deterrence against enemies ${ }^{58}$. For Hizbullah this Jihad has material and spiritual bases. Preparation for war starts not with military training, but with religious and spiritual indoctrination of Hizbullah members. Based on the religious 'promise of victory' for Jihadists, Hizbullah members do not fear battle or death. As Qassem emphasises, 'the basis is a predilection for martyrdom, not an attitude that avoids it'. This spiritual dimension has an effect on the war with Israel: 'what the enemy can do is to scare us of death, but when we debilitate this fear we progress in the direction of enhancing confidence and achieving victory.'59 Hizbullah has framed the Israeli withdrawal from Lebanese territories in 2000 and its prevention of an Israeli victory in the 2006 war as 'God's promise' (Wa'd Allah) and 'God's victory' (Nasr Allah) for believers fighting injustice. Hizbullah framed the 2006 war with Israel as a 'Divine Victory' (Nasr Ilahi). Commenting on Hizbullah's framing of the war as a 'Divine Victory', Fadlallah argues that Hizbullah's fighters were not concerned about their individual effort, but were guided by God's protection which granted them 'power beyond that of their own.'60

\footnotetext{
57 In the Open Letter Hizbullah identifies its first goal as 'Israel's complete withdrawal from Lebanon as an introduction to its total demise from existence', Ibid., p.193 58 Qassem, Hizbullah, pp. 52-3

${ }^{59}$ Ibid., pp.60-66. For further analysis of Hizbullah's perception of Jihad, see Alagha, Hizbullah's identity construction, pp. 93-4; see also Amal Saad-Ghorayeb, Hizbu'allah: Politics and Religion (London: Pluto Press, 2002), pp. 118-127.

${ }^{60}$ Mohammad Hussein Fadlallah, 'Almoukawimoun al-Badrioun wa thaqafat al intisar alIlahi' [The Badriyoun Resistance Fighters and the culture of the Divine Victory'], in alIntisar al-Moukawem: Hawiyat al-intisar wa tadaiyatihi al-stratigia' [Resistant Victory: The identity of the victory and its strategic impliations) ed. (Beirut: Islamic Centre for Cultural Studies, 2007), pp. 9-18. During the war, Fadlallah named the fighters as 'Badriyoun', referring to the Battle of Badr between the Prophet and Quraish, whilst comparing it to the Hizbullah's war with Israel. For Fadlallah, that battle imposed a new balance of power in the Arab peninsula after Quraish had dominated the scene as a power that cannot be broken. Fadlallah discusses Badr long before 2006, see his...
} 
Beyond the ideological/spiritual dimensions, Hizbullah is conscious of the material basis of its struggle with Israel. This involves due attention to the balance of power, an understanding of its enemy, and constant preparation for war. One may argue that Hizbullah's war with Israel, its presence in a divided state, and its alliance with regional states imposes a culture of constant preparation for war (as Realist International Relations theories would expect). Whilst this is true, one cannot ignore the role of ideas in driving Hizbullah towards a realist strategy-an approach, which as we saw above, is evident in Fadlallah's political thought. Because 'Jihad involves sacrifice of lives and resources', argues Qassem, 'engaging in a battle is not an impetuous [act]'; rather, the decision to go to war should be based on a clear understanding of the material balance of power. ${ }^{61}$ Nasrallah has shown that in the wake of the Israeli withdrawal in 2000, when many Lebanese were still celebrating, Hizbullah 'on the second day' began to prepare for a forthcoming war (a war that Hizbullah believed would come even before 2006). Such preparation was evident in Hizbullah's war with Israel, when the armed group used sophisticated weapons against the Israeli army. ${ }^{62}$

The prioritisation of the war with Israel has shaped Hizbullah's behaviour within Lebanon. In an attempt to protect its own Lebanese arena and limit its vulnerability towards Israel, Hizbullah committed itself to establishing a political safety net within Lebanon for most of the 1990s and 2000s. It did not join any government until 2005 (when the Syrians withdrew from Lebanon). Also, with the exception of the 2008 short armed conflict with its March 14 adversaries, Hizbullah has exercised high levels of selfrestraint to prevent the occurrence of any civil and sectarian war that would increase its susceptibility to an Israeli attack. ${ }^{63}$

Hizbullah's socialisation in Lebanon's divided state and its war with Israel also reveal the limits of ideas on political behaviour. Whilst Hizbullah's struggle against Israel is congruent with Fadlallah's ideas on liberation, the Syrian uprisings presented the most serious moral and strategic dilemma for the Islamist movement. The uprising revealed two gaps in Fadlallah's thought and Hizbullah's behaviour. What happens when an uprising occurs against a regime that is both oppressive of its people, but is also

${ }^{61}$ Qassem, Hizbullah, pp. 52-54

62 See Nasrallah's interview with Al-Mayadeen TV station, aired on 14 August 2013.

63 For an analysis of how the war with Israel dictates restraint Hizbullah's behaviour in Lebanon, see Adham Saouli, 'Hizbullah in the Civilising Process: anarchy, self-restraint and violence', Third World Quarterly, Vol. 32, No. 5 (2011), pp. 925-942. 
resisting Western and Israeli power in the region? Hizbullah chose to back Assad. For the Islamic movement, the Syrian regime is a main pillar of the 'resistance camp' (Iran, Syria, Hizbullah and formerly Hamas), and a source and conduit of arms and diplomatic support for Hizbullah. Its fall would present a grave damage for Hizbullah's war with Israel. The war with Israel, therefore, overrides any other moral considerations. ${ }^{64}$ The Syrian uprising and Syria's embeddedness in a states system, challenges Fadlallah's ideas of a common 'Islamic reality' (see below), and hence a common Islamic revival.

Secondly, Hizbullah's military intervention in the Syrian civil war raises questions about 'defensive Jihad'. Hizbullah argued that its intervention was a 'preemptive' act aiming to deter its enemies (especially Islamist extremists) from isolating Hizbullah in Lebanon. ${ }^{65}$ For both Fadlallah and Hizbullah, Jihad is a defensive act to stop and deter aggressors; but in the context of an interconnected Arab states system, where (and when) does defence and pre-emption come to an end?

\section{The Islamic state and Lebanon}

Is the Islamic state one choice amongst a menu of alternatives for Muslims? For Fadlallah and Hizbullah the 'Muslim cannot but promote the Islamic state.' 66 This answer is directly connected to the idea that Islam and politics, and hence the state, are inseparable, and is based on several assumptions. For Fadlallah, Islam, like Christianity and Judaism, is a universal ideology that if understood and applied appropriately would generate happiness and stability for humanity. Unlike Christianity, however, Islam includes a comprehensive social, economic, judicial, and political foundation for the establishment of a state. Islam is a 'state and a dawa,' (mission). ${ }^{67}$ The Islamic 'reality', the umma (community of believers), which transcends national boundaries, is

\footnotetext{
${ }^{64}$ Hizbullah justifies its stand by arguing that Assad's call for political reform and dialogue with the opposition, and his support for resistance movements makes him different from other Arab dictators. For Hizbullah's strategic dilemma and choice, see Adham Saouli 'Hizbullah, Hamas, and the Arab Uprisings: Structures, Threats, and Opportunities', ORIENT, Vol. 54, No. 2, (2013), pp. 37-44.

65 See Nawaf al-Moussawi's interview with the Lebanese Broadcasting Corporation, aired on 04 July 2013.

${ }^{66}$ Mohammad Hussein Fadlallah, Min ajl al-Islam [For Islam] (Beirut: Dar al-Malak, 2004), p. 390. Qassem argues that 'No committed Islamist, who believes in the Islamist ideology and Shari'a, can but have the project of establishing an Islamic state as one of the natural expressions of his of Islamic commitment', Qassem, Hizbullah, p. 40.

67 Fadlallah, Islam wa mantiq al-quwa, p. 267
} 
indivisible. ${ }^{68}$ Islamic movements and/or Islamic states are necessary to preserve the continuity of, and the dawa to, Islam as a universal message. Accordingly, the Islamic (world) state is the ultimate aim for the Islamist. But how can this aim be achieved? Should violence or dialogue be the tool for change? Fadlallah's answer to this question forms the theoretical basis for Hizbullah's perception of the Islamic state in Lebanon.

Fadlallah's religious interpretation, which, as argued above, is linked to his social milieu, defines two conditions in the process of establishing an Islamic state: the first through the process of $d a^{\prime} w a$ and the second by establishing the entity of Islam. This process reflects Fadlallah's long-term revolution and short-term pragmatism. ${ }^{69}$ The main features of the $d a^{\prime} w a$ phase are the representation of Islam through dialogue, persuasion and conviction. Based on the Qur'anic verse that prohibits the imposition of religion on non-believers, Fadlallah rejects the use of violence to coerce others into religion. Violence would discredit the core message of religion. For Fadlallah, this phase has a historical precedent in the Prophet's $d a^{\prime} w a$ for Islam in Mecca before his migration to Medina..$^{70}$ It is in this light that we can understand Fadlallah's intellectual and political activism in the $20^{\text {th }}$ century. He struggled to present Islam as an alternative to the secular Marxist, Liberal, and Arab Nationalist ideologies. Confident in the power of Islam, he declared that there are 'no prohibitions in dialogue' 71 and invited members of various ideological trends to the debate.

But for the Islamic message and political project to be delivered in a useful manner, the Islamist actor needs to be 'wise',72 which 'means pursuing a realist [also objective] approach that takes into consideration the existing mental, intellectual,

\footnotetext{
${ }^{68}$ Fadlallah, Min ajl al-Islam, p. 188.

${ }^{69}$ It is no coincidence that one of his biographers has portrayed him as a 'radical pragmatist', see Sankari, Fadlallah, p. 190

70 'It is known that the jihad in Mecca was one of dawa; the aim was to ingrain the main principles of the new religion...to save people from the ignorance that dominated them, and from the rigidity of the mind...a jihad, which God has considered to be the 'Grand Jihad', see, Mohammad Hussein Fadlallah, Kitab al-Jihad [The book of Jihad] (Beirut: Dar al-Malak, 1998), pp. 112-3

${ }^{71}$ Fadlallah, Min ajl al-Islam, p.376.

72 This background for this idea is found in the Quran: 'Call unto the way of the Lord with wisdom and fair exhortation, and reason with them in the better way', Sura XVI 'The Bee', in The Glorious Quran, translation by Muhammad Marmaduke Pickthall (Beirut: Dar Al-Kitab Allubnani, 1970), p. 362.
} 
psychological, and social conditions of a society before any activity is initiated.'73 Unlike the influential Egyptian Islamist thinker, Sayyid Qutb, Fadlallah did not believe that modern Muslim societies lived in a state of jahiliya (pre-Islamic ignorance); he rather called upon the Islamist to utilise modern tools to advance his message. ${ }^{74}$ In Lebanon, for example, he aimed to deconstruct orientalist views that treated Islam as backward. Islam, like Marxism and nationalism, he contended, has the right to present its world vision in a pluralist society. He invited Lebanese Christians to learn about Islam, arguing that Christianity has no basis for a political system. ${ }^{75}$ It is in the context of this phrase that Fadlallah believes in freedom of speech and ideological plurality. ${ }^{76}$ Therefore, the socio-political conditions dictate the nature of the tools the Islamist should use to achieve their goals. As to when violence or politics can be used as tool, this should largely be based on objective socio-political conditions. ${ }^{77}$

However, what happens when the Islamist state is established? For Fadlallah the emergence of a state necessitates its defence against its enemies. Once again, Fadlallah refers to the Prophet's experience in state making. For him, the migration from Mecca to Medina led to a qualitative change in Islam's existence, transforming it from a missionary campaign to a fixed entity with a material basis: a land, a people, and a government. Such an entity then required an army to defend it: for you cannot defend a state with ideas and $d a^{\prime} w a .^{78}$ Fadllallah does not provide a specific template for the fate of non-believers of Islam, but does theorise that such a state will not permit the

\footnotetext{
${ }^{73}$ Fadlallah, Kitab al-Jihad, p. 44

74 It is important to mention, however, that Fadlallah was influenced by Sayyid Qutb's work. His book Tafsir Min Wahi al-Quran [Explanation from the Quran's revelation] (Beirut: Dar Al-Malak, 1998) is similar to Qutb's 'Fi Zilal al-Quran' [In the Shade of the Quran'], (Beirut: Dar al-Shuruk, 1974). I thank Hussein Abdulsater for pointing out this to me.

75 These discussions were particularly salient in Lebanon of the 1980s when the divided country was searching for a new political and constitutional arrangement.

76 Fadlallah considered Lebanon to be-or should be-'an arena of dialogue'. See his various interviews collected in Fadlallah, Min ajl al-Islam.

77 Or what social movements theories conceptualise as structures of opportunities and constraints. These conditions either enable or constraint a political actor's ability to achieve its goals. Charles Tilly, Regimes and Repertoires (Chicago: University of Chicago Press, 2006).
}

${ }^{78}$ Fadlallah, Kitab al-Jihad, pp. 117-8 
presence of ideas that threaten the ideological basis-the $d a^{\prime} w a-$ on which the Islamic state is built. ${ }^{79}$

Fadlallah's political thought is telling of Hizbullah political world vision. Its Open Letter directly reflects Fadlallah's theory: 'we do not want to impose Islam on any one' it stated, 'but we are convinced by Islam... and ask everyone to get to know it... We call for the application of an Islamic system based on free and direct choice of the people, not by imposition'. But in his book on Hizbullah, which represents a pragmatist vision, Qassem makes explicit the difference between theory and practice: on a 'practical level there should be a [social] basis for the establishment of such as state, and this foundation is the people who have a right to choose the system of government that will rule it'. ${ }^{80}$ This vision paved the way for Hizbullah's socialisation in Lebanon, giving the revolutionary movement the religious/intellectual basis to focus its energies on the armed struggle against Israel and Western influence in Lebanon over and above other ideological goals. But what does Hizbullah's integration in Lebanon tell us about Fadlallah's religiopolitical ideas?

As we have seen, based on his religious interpretation, Fadlallah called for 'unity' among Muslims, and mutual understanding between Muslims and Christians. He also hoped for an Islamic state to develop out of dialogue and then protect itself against its foes. Whilst Hizbullah embodies Fadlallah's aim of establishing a strong and committed religious movement, the socialisation of the Islamic movement in divided Lebanon and its struggle with Israel reveals some of the limits of Fadlallah's ideas. In establishing its religio-political influence on Lebanon's Shi'a-Muslim sphere, Hizbullah threatened the power of Amal. ${ }^{81}$ Whilst Hizbullah did not create its 'state' as such, it spread its ideology, controlled certain areas, and advanced its more radical strategy in relation to Israel.

\footnotetext{
${ }^{79}$ Ibid. pp. 55-63.

${ }^{80}$ Qassem, Hizbullah, pp.40-41. Qassem builds on the same Quranic verses as Fadlallah does. See Op.cit. Writing in the mid-1990s, Hassan Fadlallah also reflects Fadlallah's gradualism when he states that Hizbullah's project in Lebanon is foundational phase, for it takes into consideration the Lebanese sectarian and political plurality which does not permit the successful establishment of an Islamic state, see Hassan Fadlallah, Al-Khiyar al akhar: Hizbullah, assira alzatiya wal mawkef [The Alternative Choice: Hizbullah, a stand and a biography of the organisation) (Beirut, Dar al-Hadi: 1994), pp.90-91. ${ }^{81}$ Amal is influenced by the religo-political school of Musa al-Sadr and Ayatollah Mahammad Shamseddine more than is Hizbullah. Accordingly, although both Hizbullah and Amal now share a similar view of the question of Lebanon as an entity, in the early 1980s they had varying views, see Saouli, Hizbullah in the Civilising Process, pp. 925-942.
} 
Such a process led to a military clash between Hizbullah and Amal in a struggle to control Shi'a-Muslim areas of Lebanon. In expressing loyalty to Iran's Khomeini, not only did Hizbullah provide the Islamic Republic with political and military influence in Lebanon, but it also challenged the influence of other regional states, especially Syria. The bloody conflict with Amal in the late 1980s was, therefore, also a reflection of Iranian-Syrian competition in the Muslim areas of Lebanon. Here the survival of an Islamist political group clashed with the idea of Muslim unity.

Despite Hizbullah's insistence that it would not impose an Islamic government, in the perception of its Christian and, as of 2005, Sunni adversaries, the movement's religious ideology, its ties to Islamic Iran, and commitment to Palestine, trumpeted its commitment to Lebanon as a sovereign entity and endangered the country's consociational model. ${ }^{82}$ Fadlallah was correct to argue that the conflict in Lebanon was not 'religious', because in his view Christianity had no religious basis for the state, ${ }^{83}$ but he underestimated the communal ties and fears that drive sectarian groups in Lebanon, regardless of their religious identity. Notwithstanding the intellectual universal appeal of his message, evidence has shown that leaders of various sectarian communities in Lebanon have failed to go beyond the consociational sectarian political system. The Taif Accord, which ended the Lebanese war, and that promised but failed to lift Lebanon from its chronic sectarianism, was one such example. It reflects the imposition of sociopolitical contexts on intellectual ideas and political behaviour. This imposition dictated Fadlallah and Hizbullah's responses to Lebanon's multi-sectarian context.

In the late 1980s, Fadlallah proposed, but failed to develop, the idea of Dawlat alInsan (literally Human State), a transient democratic regime, which acts as a precursor to establish an Islamic state, that is based on individual freedom and sectarian and political pluralism. Fadlallah noted that 'we advocate Islam, but if the [present] situation is not conducive to propelling Islam to a position of governance, then we propound the state of Man'.84

Similar to other Lebanese political forces, Hizbullah continued to express opposition to Lebanon's sectarian system. But, motivated by its war with Israel, and by a

\footnotetext{
${ }^{82}$ For an analysis of Hizbullah's perception of the state and nation, see Saad-Ghorayeb, Hizbu'allah: politics and religion, pp. 59-80.

83 See his numerous interviews on the topic collected in Fadlallah, min ajl al-Islam, pp.389-390.

${ }^{84}$ Quoted in Sankari, Fadlallah, p. 239
} 
need to legitimise its resistance as Lebanese, the Islamist movement came closer to accepting Lebanon's political context. Its 2009 manifesto tones down Hizbullah's Islamist, globalist identity. Although it did not radically shift Hizbullah's ideology as it was stipulated in the Open Letter, it accentuated Lebanon 'the Homeland', highlighting its sectarian and political plurality, and accepting the country's consociational democracy, until conditions are ripe for the elimination of the sectarian system and the establishment of a true democracy where the majority can rule. 85

\section{Wilayat al-Fakih and Islamic Iran}

Given what has been presented so far, it should come as no surprise that Fadlallah was a passionate supporter of the Islamic Revolution. Khomeini's political thought, which developed the Shi'a politico-religious concept of Wilayat al-Fakih and which promoted Islam as a resistance movement against imperialism, advancing a 'no east, no west' ideology, is congruent with Fadlallah's intellectual and political mission. Theoretically, the Islamic Republic formed an arena where Fadlallah and Hizbullah spheres intersected; but politically, Fadlallah's ascent to become marja'a in 1995, which posed a religious challenge to Khamenaei, Khomeini's successor, formed an area of contention between the two actors.

Fadlallah was not a 'mouthpiece of Iran's revolutionary agenda in Lebanon', but he was an intellectual disseminator of Khomeini's ideology. 86 In a series of lectures delivered in the 1980s, Fadlallah justified Khomeini's political idea. Wilayat al-Faqih (Guardianship of the Jurist) follows the $d a^{\prime} w a$ and the establishment of a state. As shari'a forms the constitution of such a state, the question that arises is who would be most qualified to safeguard the right application of sharia and preserve the continuity of the dawa. For Fadlallah, Islam is 'dawa wa dawla' (a mission and a state) ${ }^{87}$; the qualified person to guard such a state is the one who is most knowledgeable in religious affairs: the Faqih (jurist). Fadlallah argues that as God's messenger the Prophet Mohammad's mission did not end with da'wa. Rather, in establishing a state in Mecca, the Prophet Mohammad became the first 'Wali', ruler of Muslims. For Fadlallah this rule was neither

\footnotetext{
85 http://www.moqawama.org/essaydetailsf.php?eid=16245\&fid=47

86 Compare with Sankari, Fadlallah, p. 230.

87 Fadlallah, al-Islam wa mantiq al-quwa, p.267
} 
divine nor absolute, as 'Orientalists' argue. ${ }^{88}$ Rather, the politico-religious authority of the ruler, including that of the Prophet, was determined not by individual drives and interests, but by shari'a that governs the relationship among people, and between people and the state. ${ }^{89}$

It is on these religious and historical bases that Fadlallah supports the theory of Wilayat al-Faqih. As usual in his political writings and lectures, Fadlallah backs his case by referring to the Quran, Hadith and the Prophet's own experience. For him the theory of Wilayat al-Faqih is one answer to the question of Hakimiya in Islam (Governance and authority over people within the contours of shari'a). But the theory has particular resonance for Twelver Shi'i Islam, for it related to the question of who rules during the Ghaiba (occultation) of the Imam Mahdi. ${ }^{90}$ Shi'i scholars offer different answers to this question. Traditional jurists advocated an apolitical wilaya, which would be limited to collecting religious taxes, adjudicating legal disputes, and, if in a position of authority, to apply Sharia especially on the personal and social levels. ${ }^{91}$ One of these scholars was Ayatolalh al-Kho'ei, Fadlallah's own mentor. However, in his Islamic Government treatise, Imam Khomeini broadens the powers of the faqih to include the political, economic, educational and social spheres. Crucially, the faqih would have the power to decide on issues of war and peace. It is on the basis of this theory, or religious interpretation, that the main foundations of the Islamic Republic of Iran are constructed.

For Fadlallah, Iran, given its size, population, and resources, formed the central state in the Islamic umma with the potential to unite the Muslim world, to liberate it from dependence on colonial powers, and to bring it back the dignity it had lost after centuries of political and economic decline. Fadlallah considered Khomeini as the leader

\footnotetext{
${ }^{88}$ Fadlallah argues that 'Islamic government does not consist of a middle ages type of divine rule'. 'The Islamic ruler' is not an despot; rather, he resorts to shura (consultation) from a position of responsibility', Fadlallah, min ajl al-Islam, p.31. ${ }^{89}$ For a Fadlallah's perception of Wilayat al-Faqih see, Fadlallah, min ajl al-Islam, pp. 1149.

90 According to Shi'a-Islamic interpretation, the Prophet has conferred the Wilaya to his household (or Ahl al-bayt): first to Ali, his cousin and son-in-law, and then to Ali's sons and grandsons, from one Imam to the other reaching the Twelfth Imam: the Imam Mahdi who went into occultation (Ghaiba). Shi'as believe that Mahdi will return to save the oppressed and bring justice to the world. See Fadlallah, min ajal al-Islam, pp. 33 5-38 91 Fadlallah, min ajl al-Islam, pp. 33-40.
} 
of the $u m m a^{\prime} ;{ }^{92}$ Khomeini represented the leader-scholar that Fadlallah aspired to see, but probably also to become, as a leader of an Islamic state. Like Fadlallah, Khomeini wanted to revive his nation and the Muslim world by advancing Islam as an ideology, a revolution, and a state. Sankari observes how in his writings in the early 1980s Fadlallah tried to shape the debates within Iran regarding the trajectory-national or universalthe revolution should adopt. ${ }^{93}$

As such, the Islamic revolution presented an opportunity for Islamic liberation movements in the Middle East, not least for Lebanon's Shi'a. Informed by Fadlallah's political thought, inspired by the Islamic Revolution in Iran, and galvanised by the Israeli invasion of Beirut, Hizbullah found in Khomeini and his nascent Islamic model an ideological patron and, vitally, a source of military and financial support. ${ }^{94}$ The Open Letter reveals the movement's undisputed commitment to Wilayat al-Faqih, embodied in Khomeini and Islamic Iran. ${ }^{95}$

As with the establishment of an Islamic state, Hizbullah's commitment to Wilayat al-Faqih raised opposition among its Lebanese and Arab adversaries. Does Hizbullah abide by the guidance of the Faqih in Iran? Or is its behaviour shaped by Lebanese interests? Some scholars believe that Hizbullah has reinterpreted its commitment to the theory as a consequence of its political adaptation to the Lebanese socio-political context. ${ }^{96}$ Others contend that Hizbullah's integration in Lebanon, and its so-called 'Lebanonisation', is a cover for its Islamist agenda in Lebanon and the region. ${ }^{97}$ However,

92 Fadlallah, min ajl al-Islam, p.38.

${ }^{93}$ For a discussion, see Sankari, Fadlallah, p.179-80.

${ }^{94}$ Qassem, Hizbullah, p.80.

${ }^{95}$ Hizbullah's Open Letter of 1985 alludes to several features of Khomeini's political thought. It was addressed to the 'downtrodden', a Quranic concept, which as we saw was used by Fadlallah, but it is also salient in Khomeini's discourse, '. Unlike the 2009 manifesto, the Open Letter gives a globalist dimension to the movement: 'We, the sons of Hizbullah's nation, whose vanguards God has given victory in Iran and which has established the nucleus of the world's central Islamic State'. For further analysis of Hizbullah's perception of Wilayat al-Faqih, see Saad-Ghorayeb, Hizbullah: politics and religion, pp. 64-68.

${ }^{96}$ See for example, Joseph Alagha, 'Wilayat Al-Faqih and Hizbullah's relations with Iran', Journal of Arabic and Islamic Studies, 10 (2010), found at http://www.lancs.ac.uk/jais/volume/docs/vol10/v10_02_Alagha_24-44.pdf, accessed on 29 July 2013.

97 Fayez Qazzi, Min hassan nassrallah ila michel aoun: kiraa siyasiya li hizbulla (From Hassan Nassrallah Michel Aoun: A Political Reading of Hezbollah), (Beirut: Riad El-Rayes Books, 2009). 
if we look at the realism Hizbullah absorbed from Fadlallah and developed from its political socialisation, it becomes clear that the Islamist-Lebanese movement treats Wilayat al-Faqih, just as it does the Islamic state: as a fixed ideological goal, which requires the 'specific conditions for its implementation', within Lebanon. Two factors are of interest for this study.

First, Hizbullah's socialisation in Lebanon and its war with Israel have not only constrained its Islamist agenda, but have also imposed a need to reframe its commitment to and relation with Wilayat al-Faqih, going beyond Fadlallah's understanding of Wilayat al-Faqih. At an intellectual level, we see a development in the party's perception of the Faqih. Although the party maintains an 'organic' relationship to the Faqih, ${ }^{98}$ for Qassem, the Faqih takes into consideration two factors in the application of his wilaya: first, the application of sharia; and second, the 'specific and objective circumstances of each community or country, which influences the nature of their commitment to the Fakih'.99 In one response to his party's critics, Nasrallah has both reiterated his movement's commitment to the Faqih, but added a qualification:

'I am honored to be a member in the party of wilāyat al-faqīh. The just, knowledgeable, wise, courageous, righteous, honest, and faithful faqīh... Wilāyat al-faqīh tells us [i.e. Hizbullah] that Lebanon is a multiconfessional, multi-religious (mutanawwi', muta'adid) country that you have to preserve and uphold'. ${ }^{100}$

Second, it is important to emphasise that Hizbullah's commitment is not a mere ideological and/or intellectual stand. In addition to being an ideological patron, Iran is a strategic and external ally that supports Hizbullah's resistance against Israel. In turn, Iran perceives Hizbullah (along with the Syrian regime and increasingly Iraq) as a crucial ally to prevent the Islamic Republic's isolation in the Middle East region. Hizbullah's position and role in this politico-strategic alliance is crucial for its survival as an armed political movement. As such, despite Hizbullah's political adaptation in Lebanon, its relations to Islamic Iran did not alter. As we saw above, when it comes to strategic choices Hizbullah's commitment to Iran is unrelenting. ${ }^{101}$

${ }^{98}$ Fadlallah, al-Khiar al-Akhar, pp. 41-3.

${ }^{99}$ As such, for Qassem: 'Hizbullah's behaviour constitutes a symbiosis of an Islamic approach and Lebanese citizenship'. Qassem, Hizbullah, 79.

100 Nassrallah quoted in Alagha, Wilayat Al-Faqih, p. 39

101 For an alternative view, see Ibid., see Alagha, Wilayat Al-Faqih. 
But it is also in the context of Hizbullah's interdependence with Iran that we can understand the divergence between it and Fadlallah in the 1990s. After the death of Khomeini in 1989 and Abul al-Qassem al-Kho'ei in 1992, a disagreement emerged between Fadlallah and Khamenaei (Khomeini's successor and Iran's current supreme leader), first on who should succeed Khomeini. ${ }^{102}$ But then when Fadlallah announced his Marja'iyya in 1995, his relations with Hizbullah, which previously had pledged allegiance to Khamenei, strained. In the perceptions of Khamanei's supporters, and especially Hizbullah, Fadlallah was 'challenging the authority and credentials of the sole and supreme marja'. As Sankari observes, 'Fadlallah became the target of a systematic campaign of criticism'; his critics accused him of causing sedition within the Shi'a community. ${ }^{103}$ Fadlallah's attempts to modernise the marja'iyya, ${ }^{104}$ his criticism of selfflagellation-which is performed during Ashura - as backward and religiously illegal, and his controversial and largely progressive views regarding women's rights, led some to boycott him and to censor his books in Iran and Lebanon.

But these events, nevertheless, did not isolate Fadlallah. He became very popular because of his modernising efforts and his independence from Iran. In his defence, Fadlallah always denied any rivalry with Iran's religious leaders and argued that the Shi'a have always had more than one marja'a; crucially, but as we have shown, he insisted that he was driven by religious, apolitical motivations. Fadlallah's autonomy was also underpinned by his economic and intellectual/religious independence. As shown above, he had his own sources of income, generated by religious taxes, and a network of social and religious services that contributed to the dissemination and support of his ideas. Furthermore, in Lebanon's weak state, it was difficult, not to say impossible, to repress Fadlallah's autonomy.

\section{Conclusion}

102 Whilst Khamenei supported the nomination of the Iranian Ayotallah al-Araki, Fadlallah backed an Iraqi-based scholar, Ayatollah al-Sistani. But with the death of the former, Khamenaei ascended to become the grand Ayatollah.

103 Sankari, Fadlallah, p.256-258.

104 Talib Aziz, 'Fadlallah and the remaking of the Marja'iya' in Linda S. Walbridge, The Most Learned of the Shi'a: The Institution of the Marja' Taqlid (NY: Oxford University Press, 2001), pp. 205-14. 
In this study I examined the impact and limits of Fadlallah's ideas on Hizbullah and the relationship that governed the two actors. Three conclusions can be drawn from the analysis. Firstly, Fadlallah's politico-religious ideas, like Max Weber's 'switchmen', have conditioned the world images of Hizbullah, determining the political path Hizbullah initiated in the 1980s. But we also realise that Hizbullah's political socialisation in Lebanese and regional politics drives the Islamic movement on a separate path that is determined by the dynamic of interest.

Secondly, Hizbullah's political socialisation reveals that external pressure on a movement can reveal inconsistencies in its political ideals and invite it to reframe them. For example, as the Syrian crisis has revealed, Hizbullah's goal of resisting occupation has contradicted another pillar in Fadlallah's and Hizbullah's ideals of resisting oppressive regimes. On the other hand, Hizbullah's political evolution and integration in Lebanon have invited an innovation in Fadlallah's thought in relation to the Islamic state and Wilayat al-Faqih. We saw how Hizbullah has reframed the relationship with Iran and Wilayat al-Faqih, which goes beyond Fadlallah's theory of 'gradualism' towards an Islamic state.

Thirdly, Hizbullah's political motives and interests reveal that the Islamic movement has prioritised its strategic relation with Iran, which can explain its allegiance to Ayatollah Khamanaei and its disagreement with Fadlallah in the 1990s. The political, military, and economic patronage Iran affords Hizbullah overrides any politicoreligious ties the movement had with Fadlallah. But despite the rupture, the paper showed that Fadlallah's politico-religious vision did not dramatically depart from the main foundations that guide Hizbullah and the Islamic Republic. 